胆道シンチグラフィーによる胆汁排泄動態からみた

\title{
胆石症と十二指腸旁乳頭部悡室
}

\author{
和歌山県立医科大学消化器外科 \\ 青木 洋三 山口 和哉川口富司嶋田浩介 \\ 上田 耕臣 川嶋 寛昭 勝見 正治

\section{SCINTIGRAPHIC OBSERVATION OF BILE EXCRETION DYNAMICS \\ IN PATIENTS WITH GALLSTONE DISEASE \\ WITH AND WITHOUT JUXTAPAPILLARY DUODENAL DIVERTICULA}

\section{Yozo AOKI, Kazuya YAMAGUCHI, Tomiji KAWAGUCHI, Kosuke SHIMADA, Koshin UEDA, Hiroaki KAWASHIMA and Masaharu KATSUMI}

Department of Gastroenterological Surgery, Wakayama Medical College

pinhole collimator 装着胆道シンチグラフィーを用いて胆石症術後89例の胆汁排泄動態を観察し た. 旁乳頭憩室併存例はこの内の 11 例， $12.4 \%$ で, 特に原発性胆管結石例では 7 例中 3 例, $42.9 \%$ と 高率に合併した。胆道シンチグラフィーから得られた time-activity curveをるとに胆道末端部から十 二指腸への胆汁排泄能を胆道末端部に怙ける radioactivity の減衰率で表現すると, 胆亳結石, 胆囊逸 脱胆管結石例では喤室の有無で差がないのに，原発性胆管結石例では䄭室合併例で著明に低下してい た。これらの結果は，旁乳頭覣室が胆道末端部括約筋機能に影響を与充, 胆汁のうっ滞，ひいては胆 管結石形成の一因たりらることを推察させるものであった。

索引用語：胆道シンチグラフィー, 胆石症, 十二指腸旁乳頭㮩室, Oddi 笳, 胆道末端部括約筋機能

\section{緒䇾}

十二指腸息室は日常臨床上しばしば遭遇する疾患で あるものの，多くは無症状であるため，加療の対象と なるものはそのごく一部に過ぎない，その中にあって 十二指腸乳頭部近傍に存在するものは，胆道末端部や 茄に影響を与えるるのがあり，いわゆる Lemmel の Papillensyndrom ${ }^{1)}$ として有名である，比較的最近に なって,この喤室と胆石症との関係が注目されるよう になり，十二指腸悡室の存在により胆道末端部括約筋 機能が障害を受け，これが胆石の形成に関与している とする報告が散見されるようになった ${ }^{213)}$.そこで排泄 性胆道シンチグラフィーの定量解析により, 胆石症術 後症例を対象に胆汁排泄動態が十二指腸馝室によりど のような修飾を受けているかを検討し, 胆道末端部括

$<1986$ 年 1 月 8 日受理 >別刷請求先：青木 洋三 T640 和歌山市 7 番丁 -1 和歌山県立医科大学消 化器外科
約筋機能と十二指腸㮩室との関係について考察した. 対象と方法

1. 昭和56年 1 月から 60 年 3 月までの 5 年 3 カ月間 に, 和歌山県立医科大学消化器外科教室に颃いて胆石 症にて手術を施行した89例を対象とした。

2.この対象はすべて術後症例で, 胆亳結石57例, 胆 管結石32例であった，胆管結石の内訳は胆震結石が胆 管内に逸脱したと考えられる胆輷結石胆管逸脱例（逸 脱群と略）25例，結石の成分が赤外スペクトル法によ り，主としてビリルビンカルシウムよりなり，胆管原 発と考兄られる原発性胆管結石例（原発群と略） 7 例 であった。両者の手術術式は胆襄摘出術，ならびに総 胆管切開・切石術，T·チューブドレナージ術のみで, それ以外の付加手術や胆道再建術は加えられなかっ た.

3. 十二指腸㮃室 (㮩室と略) は, 術前の上部消化管 バリウム透視, 排泄性胆道造影, 経皮経肝胆道造影 
(PTC), 内視鏡的逆行性胆管腪管造影 (ERCP), 術中 胆道造影, 術後の T·チューブ造影から得られた,なる ベく加圧されていない前後像から証明した。

4. 旁乳頭棃室は佐藤らの記載する定義) と従い, Vater 乳頭を中心として口側, 肛門側とも2 本目の輪 状璧の距離内, あるいは $3 \mathrm{~cm}$ までの距離内に存在する るのとした。

5. pinhole collimator 装着胆道シンチグラフィー (シンチと略) は川沜の方法5)で, 術後 1 カ月を程過し た時点で, 負血や肝機能障害のないことを確認した上 で施行した。胆管から十二指腸への胆汁排出能は川嶋 らの方法6) で胆道末端部に設定した関心領域（regin of interest, ROI と略) より得られる放射能活性 (radioactivity, RI 活性と略)の経時的消長曲線 (timeactivity curve, T-A curve と略) 上, ピークに達して

表 1 対象症例での䄭室併存率

\begin{tabular}{|c|c|c|c|}
\hline 疾患群 & 症例数 & 愳室併存例数 & 併存率 (\%) \\
\hline 胆票結石 & 57 & 3 & 5.3 \\
\hline 逸 & 25 & 5 & 20.0 \\
\hline 原 発 & 7 & 3 & 42.9 \\
\hline 全 体 & 89 & 11 & 12.4 \\
\hline
\end{tabular}

から20分間での RI 活性減衰率（rate of decrease，\%， ROD と略）で表現した。

6. 得られたデータの有意性については, Studentの t-testを用いて検定した。

\section{結 果}

\section{1. 和室併存率}

対象とした89例中㮩室を併存していたのは11例, $12.4 \%$ で，すべて旁乳頭憩室に属した(表 1 ). とりわ け原発群では 7 例中 3 例， $42.9 \%$ と高率に併存してい た。

\section{2. 秝室併存症例の概要}

表 2 に示した. 憩室はすべて十二指腸乳頭（乳頭と 略）側（膵付着側）で, 乳頭を中心に口側, 肛門側10 $\mathrm{mm}$ 以内に存在し, 胆管が稆室内に開口するタイプが 原発群 3 例中 2 例にみられた. 㦝室の大ささ, 総胆管 径, Kune のいう narrow distal segment" ${ }^{7)}$ 長さはさ まざまで, これら相互間, あるいは結石の存在部位之 の間で一定の関係は認められなかった，各群の ROD については後述する。

\section{3. 喤室の有無と ROD}

胆䨳結石群, 逸脱群, 原発群それぞれに属する症例 を, 䅫室の有無により二分し, RODの差異について検

表 2 旁乳頭覟室併存症例の概要

\begin{tabular}{|c|c|c|c|c|c|c|c|c|}
\hline \multirow[b]{2}{*}{ 群 } & \multirow[b]{2}{*}{ 症例 } & \multirow[b]{2}{*}{ 年齢 } & \multirow[b]{2}{*}{ 性 } & \multicolumn{2}{|l|}{ 㮩 } & \multirow{2}{*}{$\begin{array}{l}\text { ROD } \\
(\%)\end{array}$} & \multirow{2}{*}{$\begin{array}{c}\text { 総胆管径 } \\
(\mathrm{mm})\end{array}$} & \multirow{2}{*}{$\begin{array}{l}\text { NDS } \\
(\mathrm{mm})\end{array}$} \\
\hline & & & & 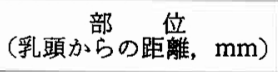 & $\begin{array}{c}\text { 大きさ } \\
\text { (縦 } \times \text { 横, } \mathrm{mm} \text { ) }\end{array}$ & & & \\
\hline \multirow[t]{3}{*}{ 䏣变結石 } & M. S. & 50 & $\mathrm{~F}$ & 下 $\cdot 5 \cdot$ 内側 & $11 \times 8$ & 83.1 & 8 & 4 \\
\hline & M. N. & 69 & $\mathbf{M}$ & 上 $\cdot 3 \cdot$ 内側 & $6 \times 4$ & 57.3 & 7 & 5 \\
\hline & N. E. & 54 & $\mathrm{~F}$ & 下・ 4 - 内側 & $7 \times 6$ & 44.4 & 9 & 7 \\
\hline \multirow[t]{5}{*}{ 逸脱 } & C. M. & 39 & $\mathrm{~F}$ & 下 $\cdot 7 \cdot$ 内側 & $5 \times 10$ & 46.0 & 13 & 10 \\
\hline & A. I. & 64 & $\mathrm{~F}$ & 上 3 - 内側 & $18 \times 22$ & 60.3 & 8 & 5 \\
\hline & T. F. & 54 & $\mathrm{~F}$ & 上 $\cdot 10 \cdot$ 内側 & $5 \times 10$ & 42.2 & 11 & 5 \\
\hline & M. U. & 70 & M & 下・ 5 - 内䁚 & $5 \times 13$ & 52.3 & 10 & 8 \\
\hline & G. A. & 34 & $\mathbf{M}$ & 上. 5 - 内側 & $8 \times 14$ & 48.3 & 13 & 5 \\
\hline \multirow[t]{3}{*}{ 原 発 } & S.M. & 77 & M & 下・ 3 - 内側 & $5 \times 10$ & 21.4 & 12 & 7 \\
\hline & I. I. & 62 & M & 憩室内開口・内側 & $12 \times 15$ & 0 & 23 & 不明 \\
\hline & S. K. & 76 & M & 憩室内開口・内側 & $30 \times 50$ & 0 & 35 & 5 \\
\hline
\end{tabular}

表 3 旁乳頭顋室の有無とROD

各数字は ROD (平均土SD)を表す。

\begin{tabular}{|c|c|c|}
\hline 群 & 想室 (一) ( n ) & 憩室 $(+)(\mathrm{n})$ \\
\hline 胆喊結石 & $64.2 \pm 12.1(54) \square \neq * *$ & $61.6 \pm 19.7(3)$ \\
\hline 兔 & $50.5 \pm 17.2(20)=7 * * *$ & $49.8 \pm 6.2(5) \Rightarrow \mathrm{ND}$ \\
\hline 原 & $22.3 \pm 25.8(4)-{ }^{*}$ & $7.1 \pm 10.0(3)$ \\
\hline
\end{tabular}

NS: 有意差枝, * : P < $0.05, \cdots *: P<0.001$
討した。その結果を表 3 に示す，㗭室を併存した群で は, 原発群の ROD は7.1 110.0 (平均 $\pm \mathrm{SD}$ ) と, 胆囊 結石群での61.6土19.7, 逸脱群での49.8土6.2に比べ, 有意に低下していた。しかし原発群について䄸室の有 無で RODを比較したところ，馝室併存群で低下する 傾向にあったが，推計学的に有意の差は誋められな かった。 
図 1 賏室内胆管開口症例の胆道シンチグラム
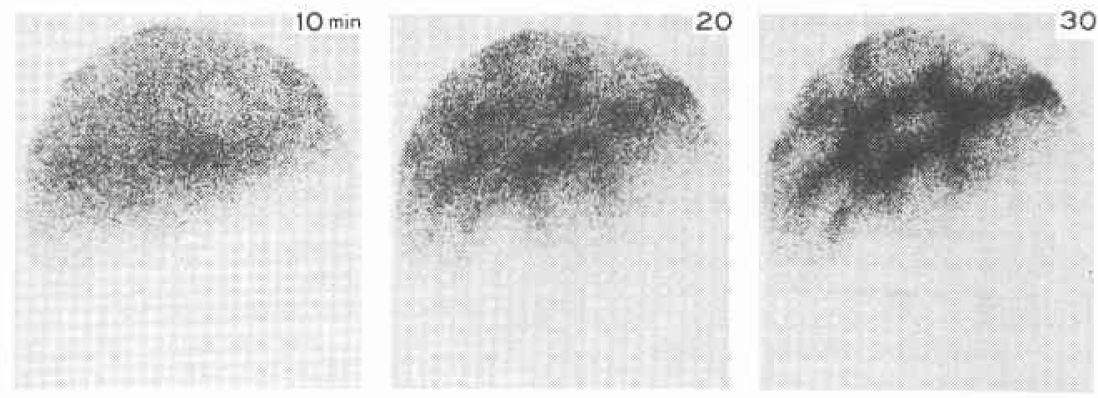

\section{留黄製㨈経口負荷}
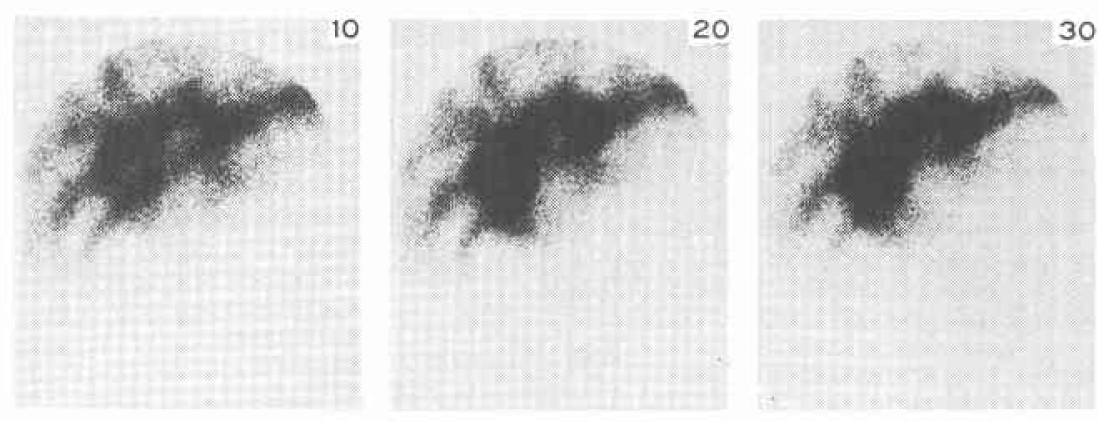

\section{4. 憩室内胆管開口症例}

この型は11例中 2 例にみられ, すべて原発群に属し た. その内の 1 例のンンチグラムと, 各 ROI での T-A curve を図 1 と図 2 に示した。 図1 のシンチグラムか らも明らかなよらにRI活性は観察し壳た60分間では 肝から胆管へは正常に移行しているものの, 胆管内に 著明に集積し，卵黄製剤の経口投与にも反応せず，十 二指腸へは全く排出されなかった。

肝, 胆道末端部 ( 2 力所), 十二指腸下行部に ROI を

因 2 憩室内胆管開口症例の各関心領域での T-A curve

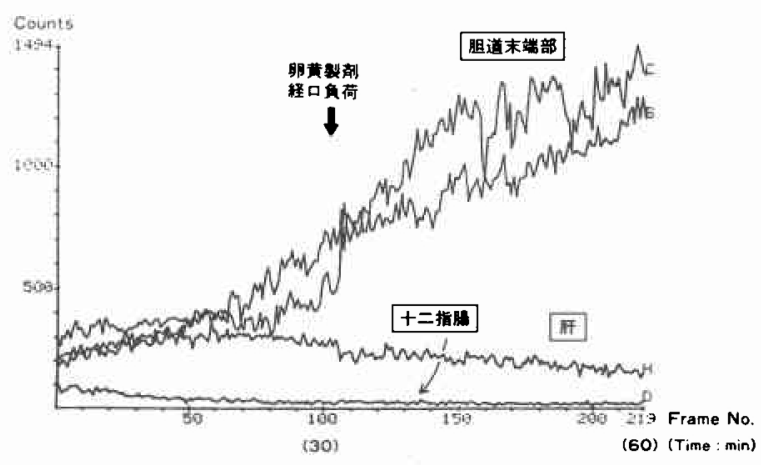

設定し得られたそれぞれの T-A curve をみると（図 2)，シンチを開始後肝での RI 活性は次第に上昇し, 15分後をピークとしてその後徐々に下降して行った。 これに代って相異なる二胆道末端部領域での RI 活性 が上昇しはじめ, 以後観察終了時るで卵黄製剤の経口 投与にも反応することなく上昇し続けた。一方十二指 腸領域での RI 活性は, 終始上昇しなかった。 他例でもこれと同様の所見であった。

5. RODの経時的改善
図 3 ROD の経時的改善

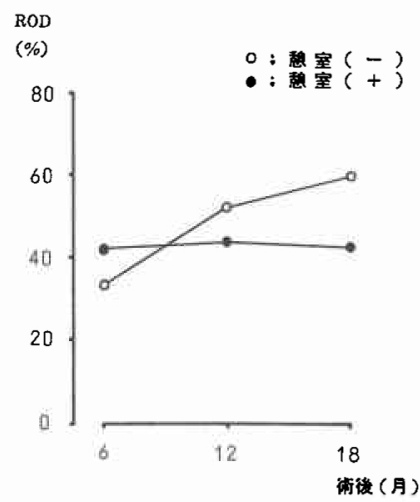


逸脱群症例について覟室の有無による ROD の経時 的変化を 6 カ月ごとに 18 月追跡した。その結果を図 3 に示した。 ここで㦝室併存症例は表 2 の症例 T.F., 54 歳, 女性例である。秝室非併存例では $6,12,18$ 力 月後に $33.0,52.3 ， 60.0 \%$ と着実な回復を示したのに 対し，䅨室併存例では $42.2 ， 44.2 ， 43.0 \%$ とさしたる 変化は示さなかった。

\section{考 察}

覟室は下行部，ことに旁乳頭部に好発し，加齢とと すにその頻度を増す4)。これは十二指腸の乳頭部近傍 が, 発生学上胎生期の前腸と中腸の痹合部に相当し ${ }^{8)}$. 抵抗減弱部となりらることに加え，十二指腸内圧の上 昇と年跲的な組織の脆弱化が発生因子として関与して いることによると思われる，その頻度はX線診断で $5 \%$, 剖検例で $20 \%$ といわれ ${ }^{9}$, 最近の手技面での向上 を考觉ると，種々の検査を駆使して発見しらる頻度は 15 20\% と想像される4)。䕀室は1710年 Chomel によ りはじめて報告され10)，1935年 Nicholsonにより䄸室 による発黄例が報告された ${ }^{11} か ゙ ，$ 胆道疾患との関連に おいて論じそれを体系化したのは Lemmel で1), Lemmel の Papillensyndrom として知られる。しかし このような臨床症状を呈するのは一部の少数例に限ら れるといわれ，これらは䕀室が胆道末端部括約筋 (Oddi 筋と略)機能に影響を及济す結果とされている. ところで一般に Oddi 筋の機能を評価する方法とし て，(1）実験動物を用いた電気生理学的方法 ${ }^{12)}$ ，(2) 術 中胆道造影法や術後 T-チューブからの造影による胆 道末端部像の解析，（3）術中術後の胆道内圧測定によ る方法 ${ }^{1314)}$, (4) ERCP の際, 経鉗子孔的に microtransducer や感圧素子を胆管内に挿入しての方法 ${ }^{15}$ など，いくつかの方法が考案され，臨床的応用がなさ れている. しかし(2), (3)は使用する装置の相違, 施 設による基準値の相違, さらに対象が手術患者に限定 されるといった問題をかかえまた(4)は手術患者以外 の症例に利用できる利点はあるすのの胆管への挿入不 能例もありらること, 一定の内視鏡操作技術を必要之 されること，被検者への苦痛がある程度伴らこと，胃， 十二指腸への内視鏡捰入による物理学的, 生理学的影 響，前投薬による薬理学的影響など，いくつかの問題 点がある。一方私達が用いたシンチによる方法は，前 処置としては絶食のみで, 特殊技術を要さず, 極めて 簡便な検查法である。被検者への侵襲も少なく， 被曝線量も少量で, より生理的条件下で施行しらる. 本研究に和いてはこのような方法を用い, ROD を定義
して画像を計量化し，䅫室の Oddi 筋に扣よぼす影響 につき検討したことを先ず言及したい．

顋室が胆石形成の原因となりらるか否かについては 詳細は不明である。しかし䇱室例での胆石合併率は Chitambar $ら 13.3 \%^{2)}$, Handelsman $518 \%{ }^{3)}$, Jones $522 \%^{16)}$, Landor $531.1 \%{ }^{17)}$, 中野ら $26.7 \%^{18)}$, 鈴木 ら $46.8 \%{ }^{19)}$ 之報告されている. Lötveit ら ${ }^{20)}$ は胆管には 異常を認めない胆䟴結石症38例について, 術中に胆管 胆汁を採取し細菌学的検索を行ったところ, 旁乳頭覣 室非併存例では陽性率が7.4\%であったのに対し, 併存 例では $81.1 \%$ と有意に高く, 検出された菌種はEscherichia coli, Krebsiella, Streptococcus faecalis, Clostridiumなどで, 併存例における胆道内への上行 感染の可能性を指摘している. L

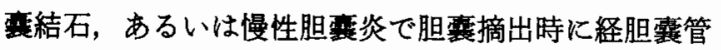
的にカテーテルを胆管の末端部側に插入し，その内圧 の差を旁乳頭秝室の有無で比較しているが，併存例で Oddi 筋のトーヌス, 収縮能ともに劣り, Oddi 筋の機能 障害，あるいは不全状態の存在を指摘している。一方 Funch-Jensen 5 22) は内視鏡的にカニニーレを十二指 腸から逆行性に胆管に㨉入し, Oddi 筋機能を旁乳頭䚑 室の有無により比較検討したが，差を証明しえなかっ た.これを受けて Viceconte ら ${ }^{23)}$ は，差が出なかった のは内視鏡時に前投薬としてアトロピン，ペチジン， ジアゼパムなどを投与していたので，これが Oddi 筋 に影響したのではないかと考兄，前投薬を施行するこ となく同様の方法で検索した。すなわち十二指腸内圧 を 0 とし, 基礎圧, 最高圧, 波高, 収縮頻度の各因子

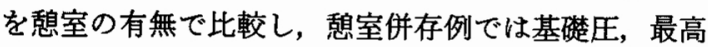
圧が低く，波高が高く，これらは何れも秝室非併存例 にくらべ推計学的に有意差が証明されたことから, 䄸 室があると Oddi 筋に機能不全が存在すると結論して いる.

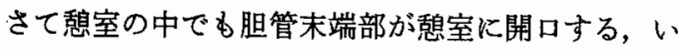
わゆる想室内胆管開口型は比較的まれな特殊なタイプ であり，1920年 Case が第 1 例目を報告している24). Costopoulos ら ${ }^{25)}$ はこのような型を12例経験し，この 内 11 例に胆管の抎張を認め, さらにこの 11 例中 6 例に 胆管結石を証明したことから，喤室内胆管開口例では 胆管や荤管系に emptying mechanism の障害がある と述べ, Willox らも同様のことを報告している26). 私 達の症例でもこの種の型を 2 例に認めた(表 2 , 図 1, 2）が，双方とも胆管原発の結石を有し，そのいずれ に执いて RODが0で，胆汁の胆管から十二指腸へ 
の著明な排泄障害の存在を示していた。したがって少

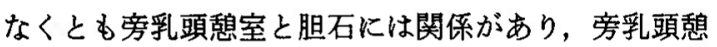
室のある症例では胆道病変の有無の検索の必要性を示 唆しているように思える。

穴沢ら ${ }^{27)}$ は胆石症 224 例中14例, 6.25\%に䕀室の併存 を認め, 一般の胆石症と異なり䅫室併存胆石症では男 女差がなく, 併存を結石の所在別にみると, 胆囊結石 では174例中 8 例, $4.4 \%$, 総胆管結石では 45 例中 6 例, $13.3 \%$ と, 後者で高頻度にみられたことに注目してい る。私達の症例でも胆石症の $12.4 \%$ に旁乳頭敗室の併 存がみられ，11例中 6 例が男性と性差がなく, 併存率 は胆亯結石群で5.3\%と低く,これに対して原発群では 7 例中 3 例， $42.9 \%$ の高率にみられた(表 1 )。他の 報告 ${ }^{2123)}$ と同じく, 旁乳頭秝室の存在により, Oddi 筋 の機能に影響し，これが十二指腸内容の胆道内逆流と 胆管内での胆汁うっ滞を促し, 上行感染が続発して胆 管結石形成の一因となりらることを表していると思わ れる。また各群でRODを比較すると（表 3 ），旁乳頭 㮩室の有無とは関係なく, 胆震結石群, 逸脱群, 原発 群の順に有意に低下し, 旁乳頭㕷室の有無による ROD の差は胆䓯結石群, 逸脱群では認められなかったが, 原発群では併存例で著しく低下して和り，今後も検討 を続けて行く必要性を感じさせた。原発群では胆道末 端部に新ける機能的, 器質的変化, ならびに胆汁排泄 能の低下が存在すること，执よびこれは旁乳頭㮩室の 存在でより顕著化することを示しているとも解され た、胆管結石の成因が Oddi 笳の異常とは考え難い逸 脱群において, ROD の経時的变化を旁乳頭秝室の有無 で比較してみると(図 3), 非併存例では改善されて行 くのに，併存例では改善されず，このことも旁乳頭秝 室が Oddi 筋の機能に影響していることの 1 つの現れ と思われた，今後症例を重ね検討したい，胆裹結石に より胆震摘出術を受け 2 年以上無症状に経過した101 名の患者で胆管結石の発生率を調べたところ, 旁乳頭 喤室非併存69例では22例，31.9\%であったのに対し， 併存32例では28例， $87.5 \%$ と有意に高率であったとす る L $\phi$ tveit らの報告 ${ }^{28)}$ も以上のことを臨床的に裏付 けている.

\section{結 語}

1. 胆道シンチグラフィーを用いて旁乳頭㮩室併存 胆石症例の胆道末端部括約筋機能について検索したと ころ, 胆震結石群, 逸脱群, 原発群の ROD はそれぞれ 61.6，49.8，7.1\%と，この順に低下していた.

2. 旁乳頭敗室併存例, とりわけ原発群の ROD は,
非併存の胆襄結石群, 逸脱群, 原発群それぞれの ROD, $64.2,50.5,22.3 \%$ に比較し低值を示し, 胆汁の十二 指腸への排泄障害が著明であった。

3.このことから, 旁乳頭数室は胆管結石形成の一因 となりらることが推察された。

な扣本論文の要旨は第14回日本胆道外科研究会（昭和60 年 5 月・長䗁)，ならびに第 2 回日本胆・桠生理機能研究会 （昭和60年 8 月・名古屋）にて発表した。

\section{文献}

1) Lemmel VG: Die klinische Bedeutung der Duodenaldivertikel. Arch Verd-Krht 56: 59-70, 1934

2) Chitambar IA, Springs C: Duodenal diverticula. Surgery $33: 768-791,1953$

3) Handelsmann JC, Murphy G, Fishbein R: Duodenal diverticulum: clinical significance and surgical treatment. Am Surg $26: 272-277$, 1960

4）佐藤寿雄, 鉄木範美 : 十二指腸㮩室の臨床. 木本誠 二監修，現代外科学大系，年間追補 $\mathrm{C}$, 東京, 中山 書店, 1978, p95-119

5）川嶋寛昭：肝・胆道シンチグラフィーによる胆道 末端部運動動態の解析一pinhole collimator に上 る画像拡大一. 日消外会誌 $18: 89-96,1985$

6）川嶋寛昭, 青木洋三, 勝見正治：胆石症に批りる胆 道末端部運動の映像解析. 胆之苹 $6: 45-52$, 1985

7) Kune GA : Current practice of biliary surgery. 1st edition, Boston, Little, Brown and Company, 1972, p25-29

8) Langman J : Medical embryology. 4th edition, Baltimore Williams \& Wilkins, 1981, p212-233

9) Burgess $\mathrm{CM}$ : Complication of surgery on duodenal diverticula. Surg Clin North Am 50 : 351-355, 1970

10) McScherry CK, Glenn F: Biliary tract obstruction and duodenal diverticula. Surg Gynecol Obstet $130: 829-836,1970$

11) Nicholson WM: Jaundice produced by a diverticulum of the duodenum. Bull Johns Hopkins Hosp $56: 305-310,1935$

12) Ishioka $T$ : Electromyographic study of the choledochoduodenal junction and duodenal wall muscle. Tohoku J Exp Med 70 : 73-84, 1959

13）宮崎逸夫, 永川宅和：胆道内圧・流量測定の意義. 外科 $38: 551-557,1976$

14）佐々 木政一,川口富司, 嶋田浩介注か：胆石症に打 ける術中胆道内圧, 流量測定より るた総胆管切開 の適応について。消外会誌 $17: 752-757,1984$ 
15）田中雅夫, 池田靖洋, 吉本英夫ほか：Microtransducerによる内視鏡的胆・茄管内王測定と乳頭部 括約筋機能検査. 胃々腸 $17: 1251-1256,1982$

16) Jones TW, Merendino KA: The perplexing duodenal diverticulum. Surgery 48 : 1068-1084, 1960

17) Landor JH, Fulkerson CC: Duodenal diverticula. Relationship to biliary tract disease. Arch Surg $93: 182-188,1966$

18）中野哲, 早川哲夫：十二指腸嚊室の臨末的意義. 一第2報, 十二指腸傍乳頭部憩室の臨床像について 一. 日臨 $33: 453-462,1975$

19）鈴木範美,高橋 渉, 木村晴茂ほか：旁乳頭㕷室と 胆道疾患の関連性について。消外会誌 11 ： 915-922, 1978

20) Lötveit T, Osnes M, Aune S: Bacteriological studies of common duct bile in patients with gallstone disease and juxta-papillary duodenal diverticula. Scand J Gastroenterol $13: 93-95$, 1978

21) L $\phi$ tveit T, Osnes M, Aune $S$ et al : Studies of the choledocho-duodenal sphincter in patients with and without juxta-papillary duodenal diveritcula. Scand J Gastroenterol 15 : 875-880, 1980

22) Funch-Jensen P, Csendes A, Kruse A et al :
Common bile duct pressure and Oddi sphincter pressure in patients with common bile duct stones with and without juxta-ampullar diverticula of the duodenum. Scand J Gastroenterol $14: 253-256,1979$

23) Viceconte G, Viceconte GW, Bogliolo G : Endoscopic manometry of the sphincter of Oddi in patients with and without juxtapapillary duodenal diverticula. Scand J Gastroenterol $19: 329-333,1984$

24) Case JT : Diverticula of small intestine, other than Meckel's diverticulum. JAMA $75: 1463$ $-1470,1920$

25) Costopoulos LB, Miller JDR : Insertion of the common bile duct and pancreatic duct into duodenal diverticula. Radiology $89: 256-262$, 1967

26) Willox GL, Costopoulos LB: Entry of common bile and pancreatic ducts into a duodenal diverticulum. Cause of pancreatobiliary disease. Arch Surg 98 : 447-450, 1960

27）穴沢雄作, 宮城伸二, 岡本祐嘉ほか：胆石症を合併 した十二指腸憩室. 臨外 $27 ： 541-548,1972$

28) L $\phi$ tveit $T$, Osnes $M$, Larsen $S$ : Recurrent biliary calculi. Duodenal diverticula as a predisposing factor. Ann Surg $196:$ 30-32, 1982 